\title{
Critically Examining Perceptions of Different Englishes in the IELTS Speaking Section: Who Decides What is Acceptable?
}

\author{
Colin Michell 8 (D) \\ Faculty, General Studies department, Higher Colleges of Technology, Fujairah, United Arab Emirates \\ $\triangle$ Corresponding Author: Colin Michell, E-mail: cmichell@hct.ac.ae
}

\begin{tabular}{|c|c|}
\hline ARTICLE INFORMATION & ABSTRACT \\
\hline $\begin{array}{l}\text { Received: March 14, } 2021 \\
\text { Accepted: April 17, } 2021 \\
\text { Volume: } 3 \\
\text { Issue: } 4 \\
\text { DOI: } 10.32996 / \text { jweep.2021.3.4.2 }\end{array}$ & $\begin{array}{l}\text { The International English Language Testing System (IELTS) has become the worldwide } \\
\text { benchmark for evaluating English language proficiency. However, the IELTS exam is } \\
\text { not without its critics. It has been accused of being elitist and unaccommodating of } \\
\text { test-takers who are not users of the prestige varieties of English, even though these } \\
\text { people may need to take the exam for employment or immigration purposes. This } \\
\text { study involved a focus group of experienced IELTS examiners who were given a }\end{array}$ \\
\hline $\begin{array}{l}\text { IELTS, Linguistic imperialism, } \\
\text { linguicism, Native speaker, non- } \\
\text { standard varieties of English }\end{array}$ & $\begin{array}{l}\text { number of listenings from non-standard yet still 'native speakers' of English to } \\
\text { evaluate using the IELTS speaking bands. The focus group found that the IELTS } \\
\text { speaking descriptors are not fit for purpose when dealing with non-standard or } \\
\text { regional varieties of English. This study makes a case for the creators of the IELTS } \\
\text { exam to adjust their grading criteria and examiner training to be more inclusive of all } \\
\text { English varieties. }\end{array}$ \\
\hline
\end{tabular}

\section{Introduction}

The International English Language Testing System (IELTS) exam's rating bands contains statements such as produces consistently accurate structures apart from 'slips' characteristic of native speaker speech (Grammatical Range and Accuracy - band 9), and is easy to understand throughout, $L 1$ accent has minimal effect on intelligibility (Pronunciation - band 8). Terms such as native speaker and $L 1$ accent can be seen as problematic when viewed through the lenses of Linguistic Imperialism, Critical Testing Theory, and World Englishes. It could be argued that these descriptions are too much of a blunt instrument that unfairly disadvantages highly proficient English users from not only the outer and expanding circle countries, but also 'native speakers' of English in the inner circle who use regional varieties of English and 'non-standard' linguistic codes. The aims of this study are to explore the perceptions of a group of experienced IELTS examiners to see if my hypothesis is an accurate assessment that the IELTS speaking bands are indeed classist, and to a degree racist and xenophobic, as they only recognise the educated middleclass speech patterns of certain powerful groups as being the ideal, and this is to the disadvantage of other users of English. This study had its origins in the early 2000s when I initially began my career as an IELTS examiner. I recall a discussion during the training where we were asked to rate a very proficient English user who used Indian English. The candidate used the constructions: "I called the dhobi to collect the washing" and "the car parked at the backside of the building". Both of these utterances were perfectly understandable within the context of the discussion, and we all rated the candidate very highly. We were then told that we should have rated the candidate much lower for using non-standard expressions. This naturally led to a very heated debate over what was acceptable within the IELTS speaking test and what was not. This incident has stayed with me and as I have since studied critical theory and linguistic imperialism, I feel I have to examine this topic further.

\section{Literature review}

What constitutes critical issues within TESOL and language teaching framework, and by extension language testing is not a completely agreed upon concept. Pennycook (1999: 334) laments the fact that it is often dismissed as being nothing more than a "mixture of TESOL and leftist politics". However, as Janks (2000) elucidates, it is far more complex than that, as critical pedagogy, which is based on a sociocultural theory of language which is designed to help students understand and navigate the relationship between language and power by highlighting the roles placed by domination, access, diversity and design. Janks

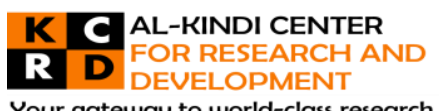

Your gateway to world-class research

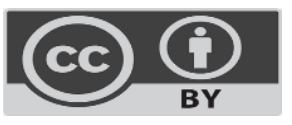

Published by Al-Kindi Center for Research and Development. Copyright (c) the author(s). This open access article is distributed under a Creative Commons Attribution (CC-BY) 4.0 license 
(2013) explains further that criticality acknowledging that languages construct us in certain ways and no language is neutral or natural, as it has been shaped by historical, geographical, environmental, political, and social conditions.

\subsection{The Hegemonic Nature of English: Who is the Native Speaker of English?}

In order to conduct any research into criticality as it applies to language testing, it is necessary to locate English Language testing and the English language itself within the broader socio-political context in order to fully appreciate the disproportionate power of English in the world. Kachru (1992) proposed the three-circles model of World Englishes. The inner circle is comprised of English derived from the first diaspora of British explorers and is comprised of countries where English is used as the primary means of communication. The inner circle is made up of the United Kingdom, The United States, Australia, New Zealand, Ireland, and Anglophone Canada and South Africa.

Figure 1: Braj Kachru's Three Circles of English

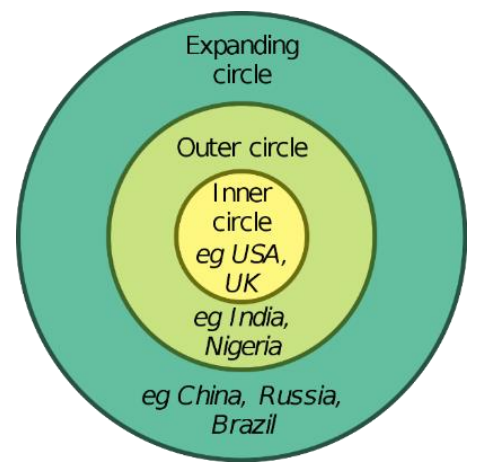

The outer circle of English came about as the second diaspora due to colonisation and the expansion of the British Empire. In countries such as India, Nigeria, and Pakistan. English may not be the home language of most of its citizens, but it serves as a useful lingua franca for education, legislature, and business. Despite the legacies of colonisation, English would still be considered more 'neutral' in the outer-circle countries than selecting an indigenous language.

The expanding circle is comprised of countries where English is a foreign language and enjoys no special official privilege, but is likely to be used in international communications. Generally, the expanding circle would include Russia, China, and Japan.

Kachru's three circles of English are particularly relevant to any discussion of criticality in English language tests such as IELTS because the inner circle countries are considered norm-providing. This means that the inner-circle countries are dictating what is and what is not correct English. This has serious implications when one is discussing power. Phillipson (1992) describes English as an imperialist language due to how it is spread around the globe and enforced by neoliberal agendas. Phillipson uses the term 'linguistic imperialism', theoretically, to emphasise that languages are hierarchical with some languages being more dominant than others. Phillipson, (1998:240) uses the term 'linguicism' to pinpoint a biased system, whereby a scheme of linguistic hierarchisation contributes to keeping people in their assigned positions, based on language use. In this sense, 'linguistic power' helps to maintain inner circle hegemony. However, there is resistance to these enforced dominant varieties of English. Even though Anglophone South Africa is considered part of the inner circle, a large segment of the population speak what is known as Black South African English (Lanham, 1996), a variety considered to have less prestige than Standard South African English. Recently, The Pan South African Language Board advised parents to be concerned if their children start speaking in the adopted British accent from the popular animated TV series Peppa Pig. A spokesperson for The Pan South African Language Board Sibusiso Nkosi was quoted by Eyewitness News (18/02/2019) as saying: "There is the perception that people have that if you have a better accent than the traditional African accent, that it is a sign of intelligence. That is not an indication of it. You can continue speaking in your African accent".

\subsection{Critical issues related to testing}

Up until fairly recently, language tests were seen as a pure measurement of abilities while overlooking any social or political aspects of testing (Shohamy, 1998). However, rather than being an isolated context-free activity, tests are intertwined with a vast range of psychological, social and political variables that have an impact on curriculum, ethicality, social classes, bureaucracy, politics and language knowledge. Language testers are now more aware of the pivotal role that language tests play in society, particularly regarding the impact these tests can have on the success or failure of individuals and groups (Messick, 1981). Tests, and language tests in particular such as IELTS and TOEFL are very powerful gatekeepers. As Madaus (1991) explained, they are mechanisms for enforcing power and control over people by virtue of being so deeply entrenched in education, government, and business. Moreover, tests are even more important than the curriculum, choice of textbook, and even the teaching 
methodology, since people are accepted or rejected based on test scores. Critical language testing takes the view that language testing can never be neutral. Instead, it is both an agent and a product of cultural, political, educational, social, and ideological agendas.

\subsection{Critical Issues Related to Examining Spoken Communication}

There is a coercive power dynamic at work in all high stakes tests, as the test-taker is required to perform certain tasks and will then be evaluated by another who controls the situation, passes judgement, and even has control over the test-taker's future (Shohamy 2001; McNamara 2012; Spolsky 2013). The IELTS exam needs to be viewed in the broader field of linguistic imperialism. Phillipson (2008: 29) explains how English has established and legitimised its power by being extensively supported by the USA and UK commercial interests, which has led to accusations of English being instrumental in the new imperialism and neoliberal empires, and that "linguistic capital, its acquisition and investment, is a prime example of symbolic power in use". According to Templer (2004), the IELTS exam is an underlying component of the cultural capital of English and is one of the primary aspects of the English Language Teaching industry's process of marketisation, commercialisation, and industrialisation, which is transforming knowledge and education into a commodity. From the test-taker's perspective, the IELTS has been found to exhibit aspects of cultural bias, and not always being culturally appropriate, as Khan (2006) noted in her study of cultural biases in the IELTS speaking exam in Bangladesh. Candidates were asked about pets in their lives, yet in Bangladesh, it is unusual to have pets, which made answering the question extremely difficult.

\subsubsection{Influence of accent and pronunciation}

George Bernard Shaw (1856-1950) famously said that it is impossible for an Englishman to open his mouth without making some other Englishman hate or despise him. This form of linguistic stereotyping is described by Rubin (2012: 11) as "a robust mechanism of social judgement whereby listeners ascribe a myriad of traits to speakers based often only very thin samples of pronunciation". Trudghill (2000) explains how some accents clearly hold more prestige than others and individuals not using the prestige variety may be prejudiced against depending on the cultural context. Skutnabb-Kangas (1989) described this form of prejudice as an example of linguicism. Phillipson (1988: 45) defined linguicism as the "ideologies and structures which are used to legitimate, effectuate, and reproduce unequal division of power and resources (both material and non-material) between groups which are defined on the basis of language". (Derwing \& Munro, 2009) describe three important aspects that must be considered when discussing accents: (1) ACCENTEDNESS describes how different a pattern of speech sounds compared to a more familiar variety. (2) COMPREHENSIBILITY is how easy or difficult it is for the listener to comprehend and decode a given speech sample. This aspect is a judgement of how difficult it is to understand rather than a measure of how much is actually comprehended. Lastly, (3) INTELLIGIBILITY, which can be defined as the degree of a listener's actual understanding of an utterance. Intelligibility is extremely difficult to assess. How does one measure how much someone has understood? In order to achieve a Band 8 on the spoken section of the IELTS test, the candidate has to fulfil the criteria of is easy to understand throughout; $L 1$ accent has minimal effect on intelligibility. To obtain a band 9, the criteria of is effortless to understand has to be exhibited (IELTS speaking band descriptors - public version); (Appendix A). Despite the very dry disinterested tone of the IELTS speaking band descriptors, people do make value judgements about people based on their accents, and occasionally these are high-stakes decisions such as a juror's assessment of a witness' credibility (Lippi-Green, 2012).

\section{Research design}

Then said they unto him, Say now Shibboleth: and he said Sibboleth: for he could not frame to pronounce it right. Then they took him, and slew him at the passages of Jordan: and there fell at that time of the Ephraimites forty and two thousand. (Judges 12:6, King James Bible). Language tests to determine who may or may not reside in a country have been in use since ancient times, as highlighted by the quote from the Biblical book of Judges. Thankfully, oral language tests today do not carry such immediate dire consequences. These are still high stakes tests that can have considerable bearing on people's futures. The goals of this study are twofold. Firstly, to critically examine the perceptions of different Englishes in the IELTS speaking module. Secondly, to examine the perceptions of which English varieties are acceptable and which are not. The overarching aim of this research is to see if the IELTS speaking exam is indeed fair to all participants, or does it still perpetuate colonial era shibboleths of what constitutes correct English that is deemed prestigious and worthy and what varieties of English are not.

\subsection{Research Methodology}

In order to conduct this research, I held a focus group with six very experienced IELTS examiners, and with the aid of focussed questions, I elicited their views. In addition to the questions, I had the group listen to six 'native' speakers of English who used regional or non-standard varieties of English and they were asked to evaluate these speakers against the IELTS speaking bands, and from the IELTS examiner training which they had all undergone. The focus group was conducted in a neutral environment and lasted for 1 hour and 9 minutes. 


\subsubsection{Participants and ethical considerations}

Before any research was conducted, I applied for ethical approval from the University of Exeter (Appendix B). I also obtained written consent from each of my participants. They were each made aware that the focus group would be recorded and then transcribed. As this study had no organisational connection, it was not necessary to get any other permission apart from the participants. The participants were concerned about their identities being revealed, thus, jeopardising their employment as IELTS examiners. The participants were made aware that their names would be pseudonymised and the recordings would be destroyed six months after the acceptance of this essay. In any qualitative study such as this, the researcher has to "rely upon the participants" willingness to express their views (Mackensie \& Knipe, 2006). The focus group consisted of seven participants, four males and three females. All seven are experienced IELTS examiners with many years of examining experience in a variety of different countries. Six of the participants self-identified as 'native' speakers of English, and they were all born, raised, and educated in inner-circle countries. Only one self-identified as a second language English speaker and was from an outer-circle country.

\subsubsection{Focus group questions}

We began the focus group by discussing questions 1 and 2 on the questionnaire (Appendix C). Although I was facilitating the discussion, I was cognisant of the need to allow each group member a chance to express their views freely, and to challenge each other if necessary. However, I needed to stay as disinterested as possible for fear of falling into the trap of "impression management whereby respondents provide answers which they think the interviewer wants to hear" (Wilson, 1997: 217). The focus group questions were based on the IELTS speaking module bands' wording and ideas and were designed to encourage the participants to respond critically. The first part of the discussion was based on the IELTS Speaking module descriptor for Grammatical Range and Accuracy (Band 9) which states that the candidate produces consistently accurate structures apart from 'slips' characteristic of native speaker speech. The two questions that were used to unpack this concept were: (1) What do you understand by the term native speaker? (2) What slips would you consider acceptable? The second part of the discussion on the descriptor for Band 8 Pronunciation states that the candidate is easy to understand throughout; $L 1$ accent has minimal effect on intelligibility. The two questions used to get the participants' views were: (1) What accents would be considered acceptable? (2) What of accents generally associated with working class people, or very distinct regional accents even if they are native speakers?

\subsubsection{Focus group listenings}

The second section of the focus group interview involved listening to seven different English speakers where the people use varieties of English that may fall outside of what IELTS considers acceptable for bands 8 and 9 . The participants were asked to give their impressions of the speakers and how they would rate the speakers and by what criteria they would use.

Table 1: Speakers for the focus group listenings

\begin{tabular}{|l|l|l|}
\hline Speaker & M/F & Dialect \\
\hline Speaker 1 & M & $\begin{array}{l}\text { Standard Irish English typical of those from Belfast. For example he } \\
\text { pronounces careful as /k3:rfal/ }\end{array}$ \\
\hline Speaker 2 & M & White working class South African English \\
\hline Speaker 3 & F & Upper-working class Merseyside (Liverpool) English \\
\hline Speaker 4 & M & $\begin{array}{l}\text { Educated Indian English. He uses the labial fricative /V/ instead of the } \\
\text { labio-velar /w/./VIə(r)d/ instead of /wiə(r)d/ }\end{array}$ \\
\hline Speaker 5 & M & $\begin{array}{l}\text { Strong working class Scottish English dialect. Unintelligible to anyone } \\
\text { unfamiliar with that particular dialect }\end{array}$ \\
\hline Speaker 6 & M & $\begin{array}{l}\text { Highly accented Jamaican patois with distinctive regional expressions such } \\
\text { as / and / to mean we. There /ðeə/ is pronounced as der /deə/ }\end{array}$ \\
\hline Speaker 7 & M & $\begin{array}{l}\text { Southern United States English. Very distinctive accent and overuses lexical } \\
\text { items such as reckon and y'all }\end{array}$ \\
\hline
\end{tabular}

\subsubsection{Implications for future IELTS speaker rating training}

The final part of the focus group raised the issues of what IELTS could do with regards to training its examiners and changing policies to be more accommodating of different English varieties. 


\subsection{Data Collection and analysis}

Once the recordings had been transcribed a thematic analysis was undertaken.

Clarke and Braun (2013) state that the purpose of a thematic analysis is to find patterns in the data that are relevant or of interest which are then used to elucidate further on the topic. A thematic analysis is not just a summary of the data, but rather an attempt to unpack the data to find underlying themes. A thematic analysis can be divided into two levels: semantic and latent. A semantic theme only analyses the surface level data without looking further than what the participant has said, whereas a latent thematic analysis looks beyond the surface features and "starts to identify or examine the underlying ideas, assumptions, and conceptualisations - and ideologies - that are theorised as shaping or informing the semantic content of the data" (p.84).

\section{Findings}

In this section, I will discuss the themes that emerged from the focus group.

\section{Theme 1: Native speakerism in IELTS correlates to a certain level of education}

Even though the focus group acknowledged that the native speaker was anyone who grew up using a certain language as their home language, which is in line with McArthur's (1992) definition of a native speaker as a user of a language since early childhood, as Hugo stated:

a native speaker for me is someone... if your mother tongue is your language... you're a native speaker of that... and if there are not too many influences because of that.

Despite McArthur's (1992) explanation of what a native speaker is, the group was unanimous in their assertion that a certain degree of education was needed in order to get a high band on the IELTS. As Eve points out after recalling a time she challenged IELTS on a decision she made that they disagreed with:

Well, that's the point, according to IELTS, when I said they're native speaker, absolutely, no questions asked. But IELTS instructed us that a 9 is an educated native speaker, I mean, the IELTS training insists that that is what is acceptable

This was definitely a concern for some of the participants who were uncomfortable with the notion that a speaking test was inadvertently testing something else. As Kenny points out:

But what do you mean by educated? I think a native speaker is anyone who grows up using English as their native tongue to communicate their thoughts and feelings. Even if they didn't go to college or university, they're still a native speaker.

Although it was acknowledged that a certain degree of education was necessary to keep talking coherently on a topic for any length of time and have the vocabulary necessary to be able discuss certain topics. Bill explained the need for good general knowledge to get a high band score:

I suppose anybody from those countries that ... You know, where they grew up speaking English, usually, but at the same time there is an element of required education I think. Just because you are hitting all those things you've got to have some kind of education, some kind of knowledge to be able to keep on rolling about whatever topic. So it's terribly difficult. I think that there's, as one of my friends here said, it does play a big part because having the context to do one of the long terms in IELTS requires some knowledge of the culture of English as well, not just the knowledge of the language.

\section{Theme 2: Whose English is valued?}

Native speakers of all languages differ from each other in aspects of grammar, pronunciation, and lexical choice, and this happens for a number of different reasons such as social and geographical dialectal reasons. This raises the question of which native speaker should be used as a model? (Cook, 1999). In addition to those rather prosaic reasons, one has to consider that there is a definite political agenda behind the spread of English and tests like the IELTS are part of that neo-liberal agenda (Phillipson, 2008), and in order to maintain that hegemonic control of English, only certain varieties of English are considered acceptable and these are quite classist in nature (Trudgill, 2000). Jess and Eve explain the dilemmas they have experienced in giving native speakers of English high band scores when they are users of regional varieties of English

Jess: I examined in the UK for 18 months and most, or a lot of people were native speakers but it was the North of England so (inaudible: ...Sutherland) so they had quite strong accents and they didn't speak grammatically and they weren't getting nines. 
Eve: I went into a shopping mall in the Summer...there were two older people, one of them said "oh there ain't enough for me 'ere" ...this is not (unclear*) ...that! I mean would you give them a 9?

\section{Theme 3: The effect of accent}

The IELTS speaking Band rubric for Band 8 pronunciation states that the candidate is easy to understand throughout; $L 1$ accent has minimal effect on intelligibility, and Band 6 states that the candidate can generally be understood throughout, though mispronunciation of individual words or sounds reduces clarity at times. Tiewtrakul \& Fletcher (2010) in discussing the high-stakes English for Aviation test claim that even if all terminology is standardised, it is still difficult to overcome the hurdles of accents and local language idiosyncrasies, and these problems are likely to be exacerbated by cultural interpretations particularly in stressful situations. Therefore, the interpretation of accent is subjective, and to a degree, at the mercy of the examiner, as Hugo elucidated:

Hugo: At the same time it depends how your ears are trained... to listening to a certain language, someone who has lived in China for, say, for ten years and he examines a Chinese and then I examine a Chinese, that would be a completely different experience for me...

From a critical perspective, it is essential to consider the effect that an accent can have on a listener. Beinhoff (2013) talks of how people can be discriminated against, or unfairly favoured depending on their accent. In the case of IELTS, some candidates were able to get a higher band score by using a higher prestige accent to offset other linguistic deficiencies, As explained by Bill and Hugo.

Bill: But can an accent help a student? Because I had a friend in China who spoke very proper British English and she got a 7 and $a$ half on the IELTS. If I had examined her today, in that situation, I don't think I would have given her a 7 and a half but I think it helped her.

Hugo: Some of the examiners are tricked by that... the guy was interviewed and I did the second one, so I was listening and relaxed with the scripts in front of me .... and I gave her 6, 6, 6 and 7. So she was overall 6. The examiner who had done her originally, she had given her an 8 and a half. Because she said: "I was so tired, it was 4 o'clock..." and she came in and she was quite like native, she was... she had very good native... just like a native accent.

\section{Discussion}

The findings from this study underscore the tenets of the principles of the politics of assessment. The participants clearly referenced examples of how the IELTS exam is influenced by ideological, political, and economic agendas (Troudi, 2018). Despite IELTS' assertion that the test reflects real-life situations around the world and is unbiased and fair to all test takers, whatever their background, and recognises all standard varieties of native-speaker English, including North American and British (IELTS.org, 2019), it is clear that in reality this goal has not been attained.

The idea of who is a native speaker of English seems, on the surface, to be an easily answered question. The straight answer should be anyone who speaks English as their home language or mother-tongue. However, the participants acknowledged that it was not quite as simple as saying anyone whose home language is English should be treated as a native speaker when attempting the IELTS exam. A certain degree of education is required to get a higher band. This would make sense if one were to only consider the Academic IELTS, as that is designed for those who wish to embark on an academic path. I would argue that this is an unfair roadblock for those doing the General IELTS, as the test should only be testing the candidates' ability to use English not their intelligence or education levels.

Moving to the theme of whose English is valued raised the issues of candidates, who despite being 'native speakers' from the norm providing inner-circle countries that do not use the prestige varieties associated with the educated middle class are often discriminated against in the speaking test. This discrimination can be worse for high-level English users from the outer-circle countries who may be completely fluent and understandable but tend towards using speech patterns and lexical chunks that are in common usage where they come from. This begs the question of just how committed IELTS is to creating test conditions that are unbiased and fair to all test takers if examiners are forced to only consider a narrow range of acceptable varieties.

The third theme that emerged was that of the effect of accent on the examiner. As the literature showed, a person's accent has an immediate effect on the listener and this is especially true with native speakers from regional areas, or those with what would be considered working class accents and speech patterns, as they do not fit into IELTS' narrow criteria of acceptability, This is a difficult area for examiners, as it depends on what accents and speech varieties 
he/she is accustomed to. As the participants explained, it can be easier for EFL test takers if the examiner is used to a particular accent.

O'Sullivan (2012) describes a number of testing criteria developed by Cambridge ESOL which the IELTS speaking section of the exam appears to be in violation of. (1) Ethics of language testing and a challenge to the presumed neutrality of measurement procedures, If the test is to be fair and unbiased then test takers should not be discriminated against in the rating process on the basis of background, education, and familiarity of content. (2) Learner's rights, test-takers should have the right to receive feedback or to retake a test. Presently, there is no transparency for the test-taker in how he/she is being rated. This is particularly relevant for the speaking and writing sections where there is a degree of subjectivity involved. (3) Consequential validity failure in high-stakes tests such as the IELTS can have serious consequences for the individual with regards to accessing higher education, employment, or immigration. This is why critical testing theory is so important to challenge the power structures that wish to maintain the status quo by marginalising and discriminating against those from working-class or users of regional dialects.

IELTS, as it is at the moment, is not fit for purpose when dealing with native speakers of English, and high level second language users, who do not conform to the standard middle-class educated varieties of English. As the use of English increases in the world and more people are taking ownership of English and making it their own, IELTS needs to become more accommodating of the different varieties of English and move away from the colonial era mentality of only recognising the educated varieties of the inner-circle countries.

\section{Conclusion}

High-stakes tests such as the IELTS have been increasingly used as gatekeepers to higher education and for immigration purposes. However, questions have been raised as to whether these tests are fair to all the test takers or perpetuate colonial era thinking of what constitutes worthwhile English. The results of this study show that IELTS has yet to move away from such thinking and to embrace and accept new varieties of English that are just as legitimate as the varieties used by educated speakers in the inner-circle countries. Moreover, future IELTS examiners need to be trained in world Englishes and learning how to rate different varieties of English.

\subsection{Limitations of the study}

This study was limited by the fact that it only had seven participants which makes generalising somewhat difficult. However, what I consider to be the biggest limitation of this study is that there was no input from any of the main providers of the IELTS exam, i.e. The British Council, Independent Development Programme (IDP - Australia), or Cambridge ESOL.

\subsection{Recommendations for further research}

Future research in this area could focus on low educated 'native' speakers of English to see how they can be treated more fairly so that their lack of formal education does not hinder their chances on a language use test. Further research could be done on the writing aspect as it applies to writers who use different varieties of English.

\section{References}

[1] Beinhoff, B. (2013). Perceiving identity through accent: Attitudes towards non-native speakers and their accents in English. Peter Lang Pub.

[2] Chance, J. E., \& Goldstein, A. G. (1981). Depth of processing in response to own-and other-race faces. Personality and Social Psychology Bulletin, 7(3), 475-480.

[3] Clarke, V., \& Braun, V. (2013). Teaching thematic analysis: Overcoming challenges and developing strategies for effective learning. The Psychologist, 26(2), 120-123.

[4] Cook, V. J. (1999). Going beyond the native speaker in language teaching. TESOL Quarterly, 33(2), 185-209.

[5] Derwing, T., \& Munro, M. (2009). Putting accent in its place: Rethinking obstacles to communication. Language Teaching, 42(4), 476-490.

[6] IELTS ensuring quality and fairness. (2019). IELTS Home of the IELTS English Language Test. https://www.ielts.org/about-the-test/ensuringquality-and-fairness

[7] Janks, H. (2000). Domination, Access, Diversity and Design: A synthesis for critical literacy education. Education Review, 52(2), $175-186$.

[8] Janks, H. (2013). Critical literacy in teaching and research. Education Inquiry, 4(2), 225-242.

[9] Judges 12:6. (n.d.). In King James Bible.

[10] Kachru, B. (1992). The Other Tongue: English across cultures. University of Illinois Press.

[11] Khan, R. (2006). The IELTS Speaking Test: Analysing Culture Bias. Malaysian Journal of ELT Research, 2, 61-79.

[12] Lanham, L. (1996). A History of English in South Africa. Focus on South Africa. In M. Görlach (Ed.), Varieties of English around the World, General Series (15th ed.).

[13] Lippi-Green, R. (2012). English with an accent: Language, ideology and discrimination in the United States (2nd ed.). London: New York.

[14] Mackensie, N., \& Knipe, S. (2006). Research dilemmas: Paradigms, methods and methodology. Issues in Educational Research, 16, 4-14. 
[15] Madaus, G. (1991, February). Current trends in testing in the USA [Paper presentation]. Conference Testing and Evaluation, Feedback Strategies for Improvement of Foreign Language Learning. , The National Foreign Language Center, Washington DC.

[16] McArthur, T. (1992). Oxford Companion to the English Language. Oxford, UK: Oxford University Press.

[17] McNamara, T. (2012). Language assessments as shibboleths: a poststructuralist perspective. Applied Linguist, 33, 564-581.

[18] Messick, S. (1981). Evidence and ethics in the evaluation of tests. Educational Researcher, 10, 9-20.

[19] O'Sullivan, B. (2012). The assessment development process. In C. Coombe, P. Davidson, B. O'Sullivan, \& S. Stoynoff (Eds.), The Cambridge guide to Language assessment (pp. 47-58). Cambridge, England: Cambridge University Press.

[20] Pennycook, A. (1999). Introduction: Critical Approaches to TESOL. TESOL Quarterly, 33(3), 329-348.

[21] Phillipson, R. (1988). Linguicism: structures and ideologies in the linguistic imperialism. In J. Cummins \& T. Skutnabb-Kangas (Eds.), Minority Education: From Shame to Struggle. Avon: Multilingual Matters.

[22] Phillipson, R. (1992). Linguistic Imperialism. Oxford, Oxford University Press.

[23] Phillipson, R. (2008). The linguistic imperialism of neoliberal empire. Critical Inquiry in Language Studies, 5(1), 1-43.

[24] Rubin, D. (2012). The power of prejudice in accent perception: Reverse linguistic stereotyping and its impact on listener judgments and decisions. In J. Lewis \& K. LeVille (Eds.), Proceedings of the 3rd Pronunciation in Second Language Learning and Teaching Conference, Sept. 2011 (pp. 11-17). Ames, IA: lowa State University.

[25] Sekhotho, K. (2019). Board advises parents to monitor language over concerns with 'Peppa Pig' accent. EWN. https://ewn.co.za/2019/02/18/board-advises-parents-to-monitor-language-over-concerns-with-peppa-pigaccent?fbclid=IwAR0s5L46oLJ96TyLpukILH6W1Z45ZJDDHLR5OExq20F78gBYM2IsDeiQLQ0

[26] Shohamy, E. (1998). Critical language testing and beyond. Studies in Educational Evaluation, 24(4), 331-345.

[27] Shohamy, E. (2001). The power of tests. Pearson, New York.

[28] Skutnabb-Kangas, T., \& Phillipson, R. (1989). Mother Tongue': The Theoretical and Sociopolitical Construction of a Concept. In Ammon \& Ulrich (Eds.), Status and Function of Languages and Language Varieties. Berlin, New York: Walter de Gruyter \& Co.

[29] Spolsky, B. (2013). The influence of ethics in language assessment. In The companion to language assessment. Wiley, Walden, MA.

[30] Templer, B. (2004). High-stakes testing at high fees: Notes and queries on the International proficiency assessment market. Journal of Critical Education Policy Studies, 2(1), 189-226.

[31] Tiewtrakul, T., \& Fletcher, S. R. (2010). The challenge of regional accents for aviation English language proficiency standards: A study of difficulties in understanding in air traffic control-pilot communications. Ergonomics, 53(2), 229-239.

[32] Troudi, S. (2018). The politics of testing and assessment. In J. I. Liontis (Ed.), The TESOL Encyclopaedia of English Language Teaching (pp. 5139-5145). Hoboken, USA: John Wiley \& Sons, Inc.

[33] Trudgill, P. (2000). Sociolinguistics: An introduction to language and society (4th ed.). London: Penguin Publishers.

[34] Wilson, V. (1997). Focus Groups: a useful qualitative method for educational research. British Educational Research Journal, 23(2), 217. 